KATERyna NovikOva

Szkoła Główna Gospodarstwa Wiejskiego

w Warszawie

DOI: $10.13166 / J M S / 106044$

kate_novi@hotmail.com

JOURNAL OF MODERN

SCIENCE TOM 1/40/2019,

ANNA ORZYŁOWSKA

Wojskowa Akademia Techniczna

ania.o96@interia.pl

\title{
Human Being in the face of Contemporary Threats: Individual Security in Poland. METHODOLOGICAL IMPLICATIONS
}

\author{
JEDNOSTKA LUDZKA W OBLICZU ZAGROŻEŃ \\ WSPÓŁCZESNOŚCI: BEZPIECZEŃSTWO \\ INDYWIDUALNE W Polsce. \\ IMPLIKACJE METODOLOGICZNE
}

\begin{abstract}
This paper presents an effort of the public institutions analysis that fulfil the state obligations in terms of civic security and safety. The latter is expected to provide citizens an opportunity to construct their private lives spheres according to the individual safety standards. Therefore selected theoretical concepts concerning safety perception have been analysed. Also there are some results of the social research concerning the safety problems presented in the paper. The research was conducted on the representative sample of the adult inhabitants of Poland as well as representatives of the selected professional cohort. Conclusion along with the literature critique allowed to define the parameters of the safety and security perception as well as the place of safety in a value hierarchy of a member of the contemporary Polish society.
\end{abstract}

\section{STRESZCZENIE}

Celem niniejszego artykułu jest próba dokonania analizy, na ile instytucje publiczne realizują zobowiązania państwa związane z zapewnieniem obywatelom bezpieczeństwa, które pozwoli im na projektowanie prywatnej sfery swojego życia w zakresie potrzeb współczesnych społeczeństw według standardów bezpieczeństwa 
indywidualnego. $\mathrm{W}$ związku z powyższym poddano analizie wybrane rozważania teoretyczne, które odnoszą się do definiowania percepcji bezpieczeństwa. Analizie poddano także wyniki badań społecznych poruszających problemy związane $z$ bezpieczeństwem przez współczesne społeczeństwo polskie. Uwzględnione badania zostały przeprowadzone na reprezentatywnej próbie dorosłych mieszkańców Polski oraz przedstawicieli wybranej grupy zawodowej. Dokonane wnioskowanie wzbogacone krytyczną analizą literatury przedmiotu pozwoliło określić parametry postrzegania bezpieczeństwa oraz pozycji w hierarchii wartości współczesnego Polaka.

KEYWORDS: individual safety, threats, origins of security, human needs, contemporary Polish society

SŁOWA KLUCzowe: bezpieczeństwo indywidualne, zagrożenia, geneza bezpieczeństwa, potrzeby jednostki, współczesne społeczeństwo polskie

\section{WPROWADZENIE}

Bezpieczeństwo jako jeden z kluczowych aspektów życia współczesnego społeczeństwa odnosi się do jednostek, grup społecznych, małych i większych społeczności oraz państw. W tym aspekcie dominującym podmiotem są głównie ludzie oraz zwierzęta i przyroda nieożywiona. Dlatego też bezpieczeństwo odnosi się głównie do przestrzeni publicznej państwa, a także funkcjonowania środowiska społecznego, obszarów lokalnych, całego kraju oraz subkontynentu.

W odniesieniu do kontekstu polskiego warto zaznaczyć, że osiągnięciem polskiej transformacji ustrojowej była daleko idąca zmiana w wymiarze aksjologicznym, gospodarczym i społecznym. Szczególnie istotną wartością nowego systemu stało się włączenie do obowiązującego kanonu praw i norm podmiotowego odniesienia do praw człowieka. Poszukując implikacji metodologicznych dotyczących problemu percepcji bezpieczeństwa przez współczesne społeczeństwo polskie, warto skupić się na dwóch wymiarach. Zatem, z jednej strony, zastanowimy się, czy bezpieczeństwo jest nakazem wynikającym z określonych wzorców społeczno-kulturowych. Z drugiej strony, równie prawdopodobne może być, że bezpieczeństwo jest wartością zinternalizowaną i stanowi wyraz poziomu świadomości i odpowiedniego rozwoju 
cywilizacyjnego. W tym celu krótko przedstawimy rozwój teorii bezpieczeństwa, natomiast wyniki dostępnych badań społecznych będą stanowić uzupełnienie analizy i wzbogacą wnioskowanie.

\section{BEZPIECZEŃSTWO. \\ GENEZA ZAINTERESOWAŃ BADAWCZYCH}

Analizując genezę zainteresowań badawczych związanych z bezpieczeństwem, warto odnieść się do etymologii i pochodzenia terminu „bezpieczeństwo”. Studium literatury wskazuje, że pojęcie to pochodzi z języka łacińskiego od słowa securitas. Pierwszy człon wywodzi się od sine, czyli „bez”, natomiast drugi człon cura - czyli „zmartwienie, strach, obawa” (por. Zawisza, Ćmiel, 2012, s. 190). W rezultacie powstało pojęcie, które w ujęciu lapidarnym oznacza brak poczucia strachu i obaw. Natomiast według Słownika języka polskiego pojęcie bezpieczeństwa jest definiowane jako „stan psychiczny lub prawny, w którym jednostka ma poczucie pewności, oparcie w drugiej osobie lub w sprawnie działającym systemie prawnym; przeciwieństwo zagrożenia” (Szymczak, 1988, s. 147).

W literaturze przedmiotu oraz opracowaniach naukowych można odnaleźć desygnowanie bezpieczeństwa jako negację wobec mniej lub bardziej oczywistych zagrożeń, czyli podkreślenie przeciwieństw lub uwypuklenie pozytywnych stanów, tj. spokoju, stabilizacji, wolności. Analitycy oraz badacze zwracają uwagę przede wszystkim na dynamiczne zmiany stanów bezpieczeństwa. Wskazują oni również inną ważną perspektywę, jaką jest obserwacja wpływu czynników subiektywnych i obiektywnych, wewnętrznych i zewnętrznych na stan bezpieczeństwa.

W niniejszym rozważaniu nie można pominąć klasyka w definiowaniu bezpieczeństwa, szwajcarskiego politologa D. Freia. Już w latach 70. ubiegłego stulecia w swoim dorobku naukowym zaproponował on definiowanie problemu bezpieczeństwa w kontekście czterech stanów emocjonalnych: spokoju, pewności, wolności od zagrożeń oraz gotowości do odparcia ataku. Konsekwencją tych analiz jest ukazanie bezpieczeństwa w czterech punktach. Po pierwsze, można zidentyfikować stan „braku bezpieczeństwa wówczas, gdy występuje rzeczywiście duże zagrożenie, a postrzeganie tego zagrożenia jest prawidłowe”, czyli jako zagrożenia. Po drugie, możemy wskazać na stan 
obsesji występujący w sytuacji postrzegania nieznacznego zagrożenia jako dużego. Trzecia sytuacja jest określana jako stan fałszywego bezpieczeństwa. Zagrożenia są poważne, natomiast są lekkomyślnie postrzegane jako niewielkie. I w ostatnim punkcie stanu bezpieczeństwa - występuje wtedy, kiedy „zagrożenie zewnętrzne jest nieznaczne, a jego postrzeganie jest prawidłowe” (Stańczyk, 1996, s. 17).

W perspektywie podmiotowego wymiaru bezpieczeństwa warto odnieść się do koncepcji S. Kozieja. Tutaj bierzemy pod uwagę wszystkie jednostki mające własne interesy i wyrażające ambicje realizacji tych interesów. Mogą to być pojedynczy ludzie, różne grupy społeczne, narody, społeczności międzynarodowe oraz cała ludzkość (Koziej, 2010, s. 2).

Stosownie do wymienionych założeń oraz zbiorowości, do których się odnosi problem bezpieczeństwa, można wyróżnić następujące jego rodzaje. Po pierwsze, każdy z nas ma do czynienia $\mathrm{z}$ bezpieczeństwem indywidualnym, czyli osobowym, personalnym. Na mezopoziomie wchodzimy w sferę bezpieczeństwa grupowego, czy też w innych epokach: rodowego, plemiennego. Epokę nowoczesności niezmiennie charakteryzuje problem bezpieczeństwa na poziomie makro, a więc bezpieczeństwo narodowe (czyli najczęściej państwowe) oraz najbardziej wymykające się spod kontroli podmiotów - międzynarodowe (regionalne, a w szczególności globalne).

Z uwagi na zasięg oraz złożoność problemu, jak i wymiar naukowy należy dokładniej przybliżyć ontologię bezpieczeństwa narodowego. Ze względu na stosunek do obszaru państwa bezpieczeństwo narodowe dzieli się na wewnętrzne i zewnętrzne. Jednak ze względu na powiązania nie należy rozpatrywać tych dwóch typów osobno. Bezpieczeństwo narodowe należy rozpatrywać jako najważniejszą wartość, czołową potrzebę narodową oraz jako priorytetowy cel działalności państwa.

Jednocześnie można dostrzec, że we współczesnych państwach funkcjonujących w systemie demokratycznym największe znaczenie odgrywa bezpieczeństwo wewnętrzne. To ono stoi na straży interesów jednostek zamieszkałych w zróżnicowanych środowiskach społecznych, większych lub mniejszych liczebnie aglomeracjach miejskich, na terenie administracyjnie ograniczonym granicami państwa. Przy tym wszystkim nadrzędną rolę odgrywa bezpieczeństwo międzynarodowe. Jego podstawowe elementy to sys- 
temy polityczne państw oraz polityka zagraniczna państw. Dodatkowymi czynnikami potężnymi bezpieczeństwa międzynarodowego są globalizacja (czasami również określana jako glokalizacja), subkontynentalna regionalizacja oraz instytucjonalizacja ponadpaństwowa. Bezpieczeństwo międzynarodowe posiada szeroki zakres znaczeniowy, co w sposób syntetyczny ilustruje tabela 1. Swoim zasięgiem obejmuje ono wartość egzystencjonalną poszczególnych państw. Odnosi się również do cech wspólnych oraz wartości danego sojuszu między państwami (np. współpraca, równowaga, stabilność). W tym kontekście warto wspomnieć pojęcie pewności, bowiem „zasadniczą treścią bezpieczeństwa międzynarodowego jest eliminowanie wszelkich zagrożeń dla istnienia, przetrwania, tożsamości i rozwoju państw oraz systemów międzynarodowych, a także kształtowanie pewności tych podmiotów" (Pokruszyński, 2012, s. 157).

Tabela 1.

Obraz bezpieczeństwa międzynarodowego

\begin{tabular}{|c|c|c|c|c|}
\hline $\begin{array}{c}\text { Ujęcia } \\
\text { bezpieczeństwa }\end{array}$ & Podmiotowe & Przedmiotowe & Przestrzenne & Procesualne \\
\hline $\begin{array}{c}\text { Rodzaje } \\
\text { bezpieczeństwa }\end{array}$ & $\begin{array}{c}\text { narodowe / } \\
\text { państwowe } \\
\text { międzynarodowe }\end{array}$ & $\begin{array}{c}\text { człowieka/ ludzkie } \\
\text { atomowe } \\
\text { biologiczne } \\
\text { publiczne } \\
\text { ekologiczne } \\
\text { humanitarne } \\
\text { ideologiczne } \\
\text { ekonomiczne } \\
\text { energetyczne } \\
\text { społeczne } \\
\text { militarne } \\
\text { kulturowe } \\
\text { socjalne } \\
\text { polityczne } \\
\text { epidemiologiczne } \\
\text { kosmiczne }\end{array}$ & $\begin{array}{l}\text { lokalne } \\
\text { regionalne } \\
\text { ponadregionalne } \\
\text { subregionalne } \\
\text { globalne } \\
\text { kosmiczne }\end{array}$ & $\begin{array}{c}\text { stan } \\
\text { proces / } \\
\text { sekwencja } \\
\text { stanów }\end{array}$ \\
\hline
\end{tabular}

Źródło: Opracowanie własne na podstawie tekstów źródłowych (Zięba, 2008, s. 15-39; Kitler, 2002, s. 21; Zięba, 1999, s. 31-32; Stefanowicz, 1984, s. 18; Stańczyk, 1996, s. 18; Pawlikowska, 2004, s. 61-63). 


\section{ZAGROŻENIE: DEFINICJE, KONCEPCJE, RODZAJE}

Stan bezpieczeństwa państwa to wielowymiarowa przestrzeń, która ma związek przede wszystkim z krajową i międzynarodową gospodarką, polityką oraz z funkcjonowaniem instytucji i służb publicznych odpowiedzialnych za walkę z przestępczością, terroryzmem itp. W ocenie poziomu bezpieczeństwa wewnętrznego państwa należy brać pod uwagę również odczuwalne, subiektywne poczucie bezpieczeństwa jego obywateli oraz postrzeganie roli i znaczenia własnego kraju w międzynarodowym systemie bezpieczeństwa w obliczu potencjalnych i rzeczywistych zagrożeń.

W związku z powyższym warto przybliżyć genezę oraz odniesienie teoretyczne pojęcia „zagrożenie”. Zagrożenie to zakres zdarzeń wywołanych celowo lub losowo, które wywierają negatywny wpływ na funkcjonowanie społecznych, politycznych i gospodarczych struktur państwa, na warunki bytowania ludności oraz stan środowiska naturalnego. Zagrożenie jest przeciwieństwem bezpieczeństwa. Charakteryzuje zjawisko społeczne lub fizyczne naruszające stan spokoju, ładu, harmonii. Poczucie bezpieczeństwa, a co za tym idzie i zagrożenia dotyczy wszystkich dziedzin życia i działalności człowieka. W literaturze przedmiotu bezpieczeństwo podmiotu rozumiane jest jako proces dynamiczny, mający na celu osiąganie stanu braku zagrożeń (patrz Roman, 2015a, s. 340).

W swoim dziele „System bezpieczeństwa Polski” S. Korycki zauważył pewien dualizm $\mathrm{w}$ pojmowaniu pojęcia zagrożenie. Jest ono, $\mathrm{z}$ jednej strony, odczuciem czysto subiektywnym wynikającym $z$ oceny występujących zjawisk. Z drugiej strony, warto pamiętać, że jest to przecież obiektywny czynnik powodujący wspomniany subiektywny stan niepewności i obaw u jednostki ludzkiej (Korycki, 1994, s. 54). W kontekście globalnym subiektywny wymiar zagrożeń i bezpieczeństwa znajduje się w centrum zainteresowań tak zwanej teorii sekurytyzacji, rozwijanej przez przedstawicieli kopenhaskiej szkoły studiów nad bezpieczeństwem w stosunkach międzynarodowych i skłaniającej się do podejścia dyskursywnego. Wybrane problemy są włączane i wykluczane ze sfery bezpieczeństwa w trakcie niekończącego się procesu intersubiektywnego, nieważne bowiem, na ile są istotne obiektywnie, z natury, o ile są za takie uznawane (Fijalkowski, 2013, s. 92). W takim sensie uznanie wybranego zjawiska za zagrożenie (np. Internet bądź cyberprzestrzeń) 
może skutkować, w myśl analizy tzw. procesu sekurytyzacji, do jego takiego ograniczania, które przeczy obiektywnemu wymiarowi zagrożeń czy ryzyka (cenzura Internetu).

Do zagrożeń możemy zaliczyć między innymi takie zjawiska, które zakłócają porządek konstytucyjny oraz naruszają spokój i pewność bytu ludzi, w ujęciu fizycznym i psychicznym, jako przyczyna utraty życia lub zdrowia. W literaturze można spotkać takie środowiska występowania zagrożeń, jak lądowe, powietrzne, wodne, kosmiczne, cyberprzestrzeń (Stańczyk, 1996, s. 45; Gwoździewicz, Tomaszycki, 2017, s. 55). Wśród konkretnych zagrożeń, które występują dzisiaj w środowisku międzynarodowym, warto wspomnieć przede wszystkim terroryzm międzynarodowy oraz przestępczość zorganizowaną (również w cyberprzestrzeni), zagrożenia dla środowiska naturalnego (w tym brak wody, żywności i surowców), epidemie, a także dysproporcje rozwojowe, związane z pojęciem bezpieczeństwa ekonomicznego (Stańczyk, 1996, s. 45; Wawrzusiszyn, 2016, s. 229; Kardash, 2017, s. 109). Poziom bezpieczeństwa jako najbardziej pożądanej wartości dla każdego człowieka zależy od zmian w środowisku, które stają się czynnikami zagrożeń i rosnącego ryzyka (Szafrańska, Szafrański, 2014, s. 214).

Zagrożenia dla bezpieczeństwa państwa można podzielić na trzy zasadnicze grupy. Są to zagrożenia niemilitarne, militarne i transgraniczne, będące jednocześnie wymiarem bezpieczeństwa wewnętrznego i zewnętrznego państwa. Wśród czołowych czynników zagrożeń dla bezpieczeństwa wewnętrznego państwa można wymienić nie tylko terroryzm bądź przestępczość zorganizowaną czy tė̇ nieprzewidywalne klęski żywiołowe lub katastrofy techniczne. Są to również różnego rodzaju kryzysy polityczne zagrażające demokratycznemu porządkowi w państwie, kryzysy ekonomiczne, a także zamieszki lub fale strajków o zasięgu regionalnym lub ogólnokrajowym czy też zdarzenia naruszające porządek konstytucyjny, w tym zbrojne przewroty polityczne bądź powstania nieprzekształcone w wojnę domową. Współcześnie państwo może zetknąć się z takimi czynnikami, które bezpośrednio wpisują się w zagrożenia dla bezpieczeństwa, jak migracje masowe, wojny domowe czy wojny między państwami sąsiadującymi, prowokacje zbrojne, starcia lub incydenty graniczne, a także interwencja militarna państwa w ramach sojuszu wynikająca ze zobowiązań między- 
narodowych, realizowana w ramach przywracania lub wymuszania pokoju (Szczudlińska-Kanoś, 2013, s. 70).

W definiowaniu zagrożeń istotną kwestią jest kryterium przedmiotowe wyróżniające niebezpieczeństwo subiektywne oraz obiektywne. Jego wyznacznikiem jest postrzeganie przez podmiot określonych obszarów niepewności. Pozwala to na działania naprawcze, czyli przywrócenie odczuwalnego bezpieczeństwa. Według kryterium przedmiotowego można wyróżnić następujące zagrożenia:

Zagrożenia polityczne dla bezpieczeństwa możemy określić jako „stan, w którym nasilają się zadania zorganizowanych grup społecznych (politycznych) uniemożliwiających wypełnianie przez państwo jego głównych funkcji, a przez to osłabiające lub niweczące działania organów lub instytucji realizujących cele i interesy narodowe" (Słownik..., 2002, 153). Te zagrożenia obejmują zarazem politykę wewnętrzną i zagraniczną państwa. Zagrożenia te powstają w wyniku planowych działań, które doprowadzają do naruszenia porządku konstytucyjnego państwa, zakłócają pozycję państwa na arenie międzynarodowej, prowadzą do obalenia legalnych władz, a nawet mogą doprowadzić do wybuchu wojny domowej.

Zagrożenia ekonomiczne bezpieczeństwa narodowego dotyczą zagrożeń gospodarczych. Obejmują finanse państwa, sferę handlu, procesy produkcji i dostęp do surowców w zakresie bezpieczeństwa energetycznego (Savina, Sribna, 2016, s. 36). Zagrożenia ekonomiczne (gospodarcze) dotyczą takich zjawisk, jak kryzys finansowy, utrata rynków zbytu, ograniczanie dostępu do surowców, technologii przez inne państwa, zazwyczaj wysokorozwinięte, rozwój szarej strefy, nasilenie prania brudnych pieniędzy oraz wzrost bezrobocia (Kardash, 2017, s. 110).

Zagrożenia społeczne (psychospołeczne) odnoszą się głównie do niebezpieczeństwa utraty życia i zdrowia obywateli oraz bezpieczeństwa publicznego i socjalnego. Ich typowe symptomy to: wzrost ubóstwa, rozprzestrzenianie się chorób, nasilenie terroryzmu i patologii społecznych, wykluczenie społeczne, łamanie praw człowieka i obywatela, kryzysy demograficzne (Wyleżałek, 2012, s. 110-111; Novikova, 2015, s. 59). 
Zagrożenia ekologiczne to zdarzenia, które mogą doprowadzić do wystąpienia trwałego lub częściowego uszkodzenia lub zniszczenia danych obszarów środowiska przyrodniczego. Te zagrożenia negatywnie wpływają na zdrowie i życie jednostki. Ich źródłem mogą być czynniki antropomorficzne i nieantropomorficzne (Roman, 2015b, s. 222). Zagrożenia ekologiczne mogą być spowodowane przez siły natury, tj. susze, powodzie, opady, pożary, mrozy, wichury, trzęsienia ziemi, lawiny. Dodatkowym źródłem zagrożeń ekologicznych są konsekwencje rozwoju cywilizacyjnego: masowe zanieczyszczenie wody, powietrza i gleby, katastrofy naturalne i przemysłowe, chaotyczna urbanizacja, brak właściwego gospodarowania odpadami komunalnymi, przemysłowymi, nuklearnymi, niekontrolowane eksploatacje zasobów naturalnych, próby nuklearne oraz testy nowych typów broni itd. (Roman, 2015b, s. 223).

Terroryzm to szczególny rodzaj zagrożeń, które ciężko zaliczyć do jednego typu zagrożenia. Może być zagrożeniem społecznym oraz militarnym. Zjawisko to definiujemy jako „formę przemocy polegającą na przemyślanej akcji wymuszenia bądź zastraszenia rządów lub określonych grup społecznych w celach politycznych, ekonomicznych i innych" (Słownik..., 2002, s. 146). Nie da się rozpatrywać tego terminu wyłącznie w wymiarze zagrożenia militarnego. Źródeł terroryzmu współcześnie należy doszukiwać się również na płaszczyźnie społeczno-gospodarczej. Ponadto warto pamiętać o nowych typach terroryzmu jako elementu zagrożeń transnarodowych, takich jak cyberprzestępczość oraz cyberterroryzm (Wawrzusiszyn, 2016, s. 219-224).

Zagrożenia militarne to taki „splot zdarzeń w stosunkach międzynarodowych, w których z dużym prawdopodobieństwem może nastąpić ograniczenie lub utrata warunków do niezakłóconego bytu i rozwoju państwa, albo naruszenie bądź utrata jego suwerenności i integralności terytorialnej - w wyniku zastosowania wobec niego przemocy zbrojnej (militarnej)" (Słownik..., 2002, s. 160). Wśród rodzajów zagrożeń militarnych występują wojny, terroryzm, konflikty lokalne, spory graniczne, waśnie religijne i etniczne (Roman, 2016, s. 371, 380). W drugim dziesięcioleciu wieku XXI wojny są prawie taką samą codziennością, jak sto lat wcześniej pod koniec długiego XIX w. W specyficznych formach przenikają nawet codzienność krajów wysokorozwiniętych i względnie bezpiecznych. 
Niezwykle poważnym - w tym też w wymiarze indywidualnym - stał się obecnie inny specyficzny typ zagrożeń, który przekracza nawet charakter transgraniczny. Staje się zagrożeniem globalnym, jednocześnie mając sposobność dotknięcia życia każdej pojedynczej jednostki ludzkiej. Jest to zagrożenie technologiczne, które niewątpliwie może być częścią każdego z poprzednio wymienionych typów zagrożeń, jednak ze względu na specyfikę, wszechobecność, czyli coraz szybciej zwiększający się zasięg i nieprzewidywalność skutków, zasługuje na wydzielenie jako odrębnego rodzaju zagrożenie. W badaniach CBOS z roku 2018 zostały sprawdzone doświadczenia ludzi związane $\mathrm{z}$ technologiami informacyjnymi i komunikacyjnymi, w szczególności w kontekście prywatności oraz wybranych zagrożeń obecności online, bo aż dwie trzecie Polaków korzysta z Internetu (CBOS, 2018a, s. 5). Wśród tych wybranych zagrożeń warto odnotować wzrost znaczenia w postrzeganiu zagrożeń i bezpieczeństwa przez respondentów CBOS fake newsów, czyli informacji, które później okazują się nieprawdziwe. To zagrożenie znalazło się wyżej od wirusów, niebezpiecznych programów, obraźliwych treści, podszywania się, fałszowania tożsamości czy niepowołanego dostępu do kont lub treści prywatnych, które również reprezentują niezwykłe zagrożenie ze strony tylko technologii informacyjnych i komunikacyjnych (CBOS, 2018, s. 6). W różnorodnych analizach postępu technologicznego mówi się o wielości zagrożeń w takich sferach, jak technologie jądrowe, inżynieria genetyczna czy różne zastosowania sztucznej inteligencji. Oceniane są nie tylko zagrożenia bądź ryzyka szerokiego zastosowania technologii, ale i możliwości rozwojowe czy niezamierzone konsekwencje w wymiarze społecznym, ekonomicznym, organizacyjnym i ekologicznym (Pałka, Stecuła, 2018, s. 294).

Likwidacja skutków zagrożeń dla bezpieczeństwa, czyli zapewnienie stanu spokoju, ładu, niezagrożenia, pewności w odniesieniu do makro- i mikrostruktur społecznych, współcześnie jest przedsięwzięciem bardzo złożonym, uzależnionym od nieprzewidywalnych czynników ekonomicznych i społecznych. Okoliczności te przyczyniły się do powołania struktur międzynarodowych, między innymi takich jak Sojusz Północnoatlantycki, Unia Europejska i innych, których nadrzędnym celem była i jest likwidacja zagrożeń dla globalnego oraz indywidualnego bezpieczeństwa. 


\section{BEZPIECZEŃSTWO W SYSTEMIE WARTOŚCI CZŁOWIEKA}

Bezpieczeństwo w potocznym znaczeniu ma wiele znaczeń. Człowiek rozpatruje je jako wartość poznawczą i zinternalizowaną. Głównym i chyba najważniejszym znaczeniem jest pojmowanie go jako stanu, kiedy nie występuje zagrożenie istnienia i swobodnego działania człowieka. Abraham Maslow jako jeden z pierwszych ujmuje bezpieczeństwo jako główną i podstawową potrzebę egzystencjalną każdego człowieka. Zwrócił on także uwagę, że brak bezpieczeństwa utrudnia rozwój jednostki i nie pozwala na realizację innych potrzeb.

Wykres 1.

Czy Pana(i) zdaniem, Polska jest krajem, w którym żyje się bezpiecznie?
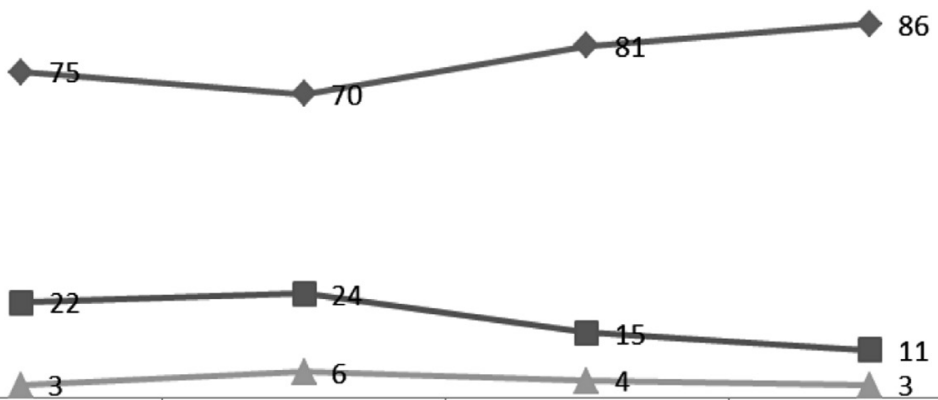

2011 r. 2014 r. 2016r. 2018 r.

$\leadsto$ tak $\_$nie $\longrightarrow$ trudno powiedzieć

Źródło: CBOS, komunikat z badań, Nr 61/2018, Poczucie bezpieczeństwa i zagrożenia przestepczością, maj 2018 r., \%.

Bezpieczeństwo umożliwia zaspokojenie głównych potrzeb o charakterze życiodajnym, a także pozwala zaspokoić człowiekowi rozwój, istnienie i przetrwanie. Dla jednostki ludzkiej bezpieczeństwo jest nadrzędną wartością społeczną w wymiarze zarówno makrostrukturalnym, jak i jednostkowym. Odzwierciedleniem empirycznym (szczegóły: wykres 1) tego założenia teoretycznego może być odniesienie się do badań społecznych przeprowadzonych w społeczeństwie polskim w 2018 roku, z których to wynika, że Polacy czują się bezpiecznie w swoim kraju. 
Wykres 2.

Czy zagrożenie dla niepodległości i suwerenności Polski ma Pana(i) zdaniem przede wszystkim charakter...?

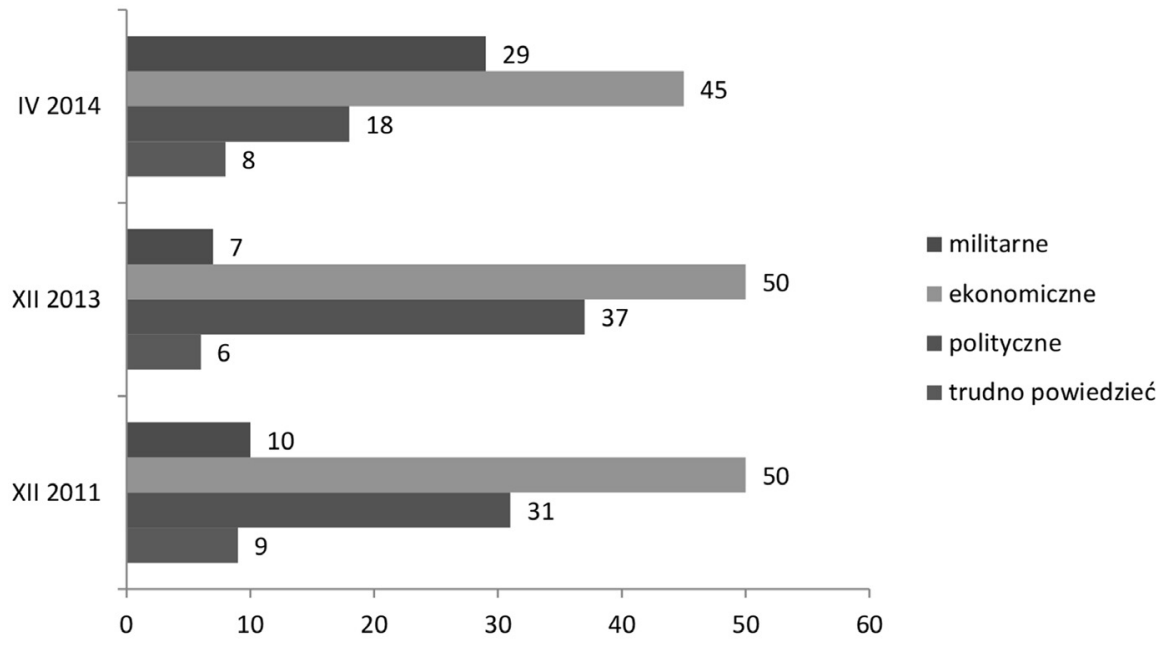

Źródło: CBOS, komunikat z badań, Polacy o bezpieczeństwie narodowym i NATO, kwiecień 2014, \%.

Kolejny wątek badań (szczegóły: wykres 2) wskazuje, że społeczeństwo polskie nie odnosi się do bezpieczeństwa i suwerennosci jako dokonanego stanu rzeczywistego. Jest to stan, który na skutek działań ekonomicznych, a także militarnych ze strony państw ościennych może ulec zmianie. Można uznać za swego rodzaju symptomatyczne postrzeganie przez zbliżoną część populacji i w dwóch różnych okresach przeciwstawnie położonych państw sąsiadujących (szczegóły badań empirycznych prezentuje wykres 3).

Analizując pojęcie bezpieczeństwa, badacze zazwyczaj stawiają akcent na piramidzie Maslowa, gdzie potrzeba bezpieczeństwa to potrzeba środowiska psychicznego i emocjonalnego (por. Zawisza, Ćmiel, 2012, s. 194-195). Zdaniem Maslowa potrzeba to stan poczucia pożądania czegoś, który jednocześnie wiąże się z pragnieniem uzupełnienia braku. Dlatego podstawę ludzkich pragnień stanowią potrzeby fizjologiczne (brak głodu, pragnienia, snu), a następnie potrzeby bezpieczeństwa (stabilizacja, ład, pokój). Wyżej znajdują się potrzeby afiliacji (uznania, przyjaźni, miłości), kolejno potrzeby szacunku i uznania, na samej górze zaś potrzeba samorealizacji (zaspokajanie ambicji), 
czyli szeroko pojętego szczęścia (por. Novikova, 2016). Według Maslowa dążenie do zaspokojenia potrzeb wyższego rzędu warunkowane jest zaspokojeniem potrzeb niższego rzędu. W jego koncepcji istotne znaczenie ma równoważne motywowanie ludzi w kierunku zaspokojenia potrzeb niższego rzędu, co z kolei warunkuje zaspokajanie kolejnych potrzeb określanych jako wyższego rzędu. Działania motywacyjne są skazane na niepowodzenie, jeśli zaspokaja się wyższy poziom potrzeb, ignorując niższy poziom (Maslow, 1990).

Wykres 3.

Których państw Polska powinna najbardziej się obawiać?

- IV 2014 r. $\quad$ v 2010 r. $\quad$ ॥II 1990 r.

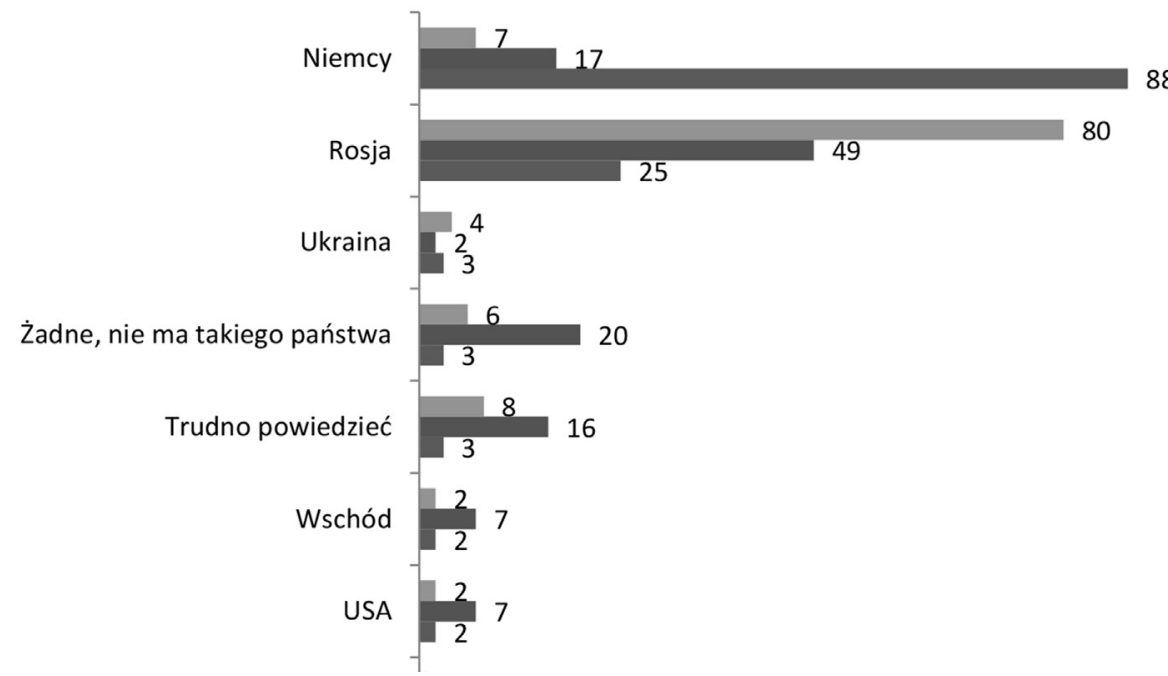

Źródło: CBOS, komunikat z badań, Polacy o bezpieczeństwie narodowym i NATO, kwiecień 2014 r., \%.

Bezpieczeństwo w koncepcji Maslowa zajmuje drugie, dość ważne miejsce i odnosi się do braku zagrożeń fizycznych i psychicznych. Dlatego warunkuje je potrzeba stabilności, ładu, ochrony, porządku, spokoju, eliminacji zagrożeń, a także sprawiedliwości. Ważnym elementem w egzystencji każdego człowieka jest zapewnienie sobie bezpieczeństwa. Potrzeba życia wolnego od trosk materialnych i niematerialnych. Zaspokojenie potrzeb bezpieczeństwa fizycznego w odniesieniu do najbliższego miejsca zamieszkania to jeden z głównych 
symptomów wartościujących poziom bezpieczeństwa jednostki ludzkiej. Potrzeby fizjologiczne i potrzebę bezpieczeństwa człowieka Maslow uznał za priorytetowe dla prawidłowego funkcjonowania organizmu ludzkiego. Jednak krytycy zarzucają mu zbyt uproszczone podejście. Ich zdaniem nie wszyscy ludzie zaspokajają potrzeby w podanej kolejności: od niższego rzędu do wyższego. Uważają także, że większość czynników może zaspokajać wiele potrzeb.

\section{JEDNOSTKA LUDZKA A BEZPIECZEŃSTWO INDYWIDUALNE}

Kontynuując rozważania na temat bezpieczeństwa jako wartości dla współczesnego człowieka, warto odwołać się do literatury oraz do dokonującej się współcześnie ewolucji bezpieczeństwa indywidualnego.

Wśród definicji znajdziemy określenie bezpieczeństwa jako potrzeby życia stabilnego czy też zrównoważonego, z takimi charakterystykami, jak trwałość, stałość, uzasadnione cele, harmonia, „zdrowy duch i umysł, ciało i społeczeństwo" (Lisiecki, 2008, s. 73). Człowiek, który ma życie niestabilne, niezrównoważone - nie odczuwa satysfakcji z egzystencji, ma odebrane prawo do bezpieczeństwa. Staje się jednostką ludzką, która oddala się od wymogów współczesnej kultury. Każdy człowiek w momencie zachwiania równowagi i stabilności dąży do zapewnienia sobie bezpieczeństwa. Jak stwierdził Maslow, „ludzie, dając wyraz obawom o bezpieczeństwo (rozwój i stabilizację), deklarując jednocześnie pragnienie jego przywrócenia, powiadają o zrównoważeniu lub zachowaniu hierarchii potrzeb, dóbr i wartości”. Po tym, jak „potrzeby fizjologiczne są względnie dobrze zaspokojone, pojawia się natychmiast nowy zestaw potrzeb, które ogólnie można określić jako potrzeby bezpieczeństwa (stabilizacji, zależności, troskliwej opieki, uwolnienia od strachu, lęku i chaosu; potrzeba struktury, porządku, prawa, ograniczeń, wsparcia w opiekunie itp.)" (Maslow, 1990, s. 76).

Szczególnie istotną wartością systemu społeczno-politycznego w Polsce na przełomie wieków XX i XXI stało się włączenie do obowiązującego kanonu praw i norm podmiotowego traktowania praw człowieka. Człowiek stał się najwyższą wartością, któremu państwo ma obowiązek zapewnić bezpieczeństwo, czyli taki stan, w którym będzie on miał zdolność do kreowania, rozwijania i ochrony ważnych dla siebie wartości przed zewnętrznymi i we- 
wnętrznymi zagrożeniami. Dlatego w ramach definiowania bezpieczeństwa indywidualnego znajdują się takie aspekty, jak przetrwanie (państwa, narodu, zachowanie egzystencji biologicznej), integralność terytorialna, niezależność polityczna oraz jakość życia obywateli.

Wcześniej bezpieczeństwo indywidualne było utożsamiane z gwarancją nienaruszalności oraz nietykalności cielesnej i ochrony mienia przed aktami przemocy ze strony przestępczych zachowań jednostek lub grup zorganizowanych. Obecnie za wymiary bezpieczeństwa indywidualnego uznawane są przede wszystkim podstawy egzystencji, w tym stabilność zawodowa i zatrudnienia, poczucie pewności i swobody rozwoju w aspekcie politycznym, ekonomicznym, gospodarczym, społecznym i ekologicznym oraz brak zagrożenia dla prawidłowego funkcjonowania prywatnej sfery życia.

Powyższe rozważania teoretyczne oraz zaprezentowane poniżej wyniki badań empirycznych (wykresy: 4, 5) pozwalają na odniesienie się do postrzegania bezpieczeństwa przez Polaków w połowie drugiego dziesięciolecia XXI w. Jako naród Polacy posiadają suwerenne państwo, ale czują się bezpiecznie tylko w otoczeniu najbliższym zamieszkania, lokalnym. Polacy ufają głównie bliższym i dalszym sąsiadom.

Wykres 4.

Czy miejsce, w którym Pan(i) mieszka (dzielnica, osiedle, wieś), można nazwać bezpiecznym i spokojnym?
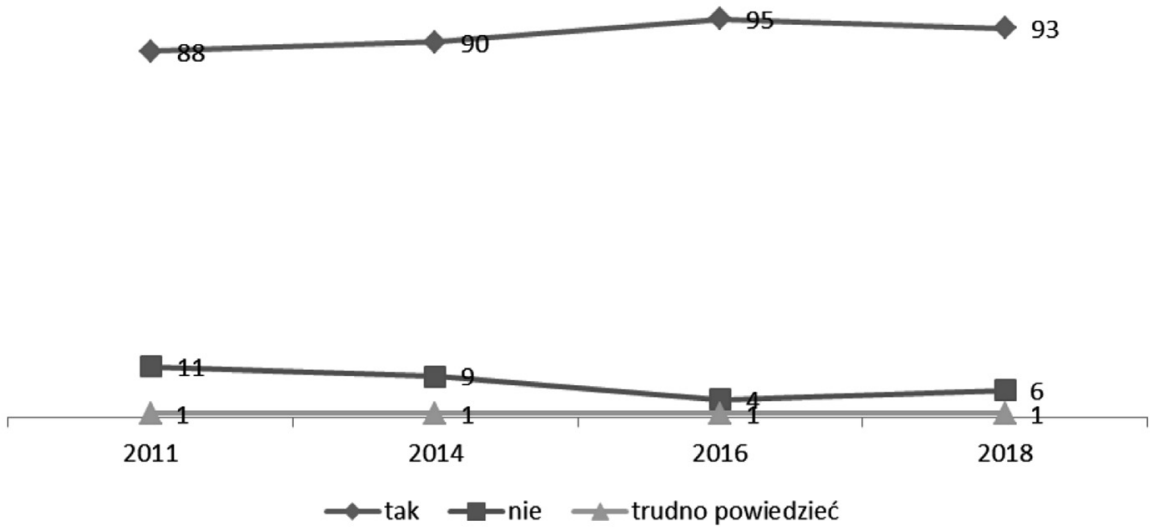

Źródło: CBOS, komunikat z badań, Nr 61/2018, Poczucie bezpieczeństwa i zagrożenia przestepczością, maj 2018 r., \%. 
Gorzej rysuje się sytuacja związana z zagrożeniem płynącym ze strony działalności przestępczej rozumianej w znaczeniu ogólnym. Zastanawiające jest, że w latach 2016-2018 liczebność populacji dostrzegającej to zagrożenie w stopniu dużym, umiarkowanym i ci, którzy jej nie dostrzegali, plasowała się na bardzo zbliżonym poziomie. Natomiast wyniki badań z roku 2018 wskazują w sposób jednoznaczny, że blisko połowa polskiego społeczeństwa nie odczuwa niepokoju związanego z sytuacjami społecznymi o charakterze przestępczym. Trudno określić, czy jest to związane z poprawą jakości pracy organów odpowiedzialnych za ochronę bezpieczeństwa, czy z innymi okolicznościami.

Wykres 5.

\section{Poczucie zagrożenia przestępczością.}
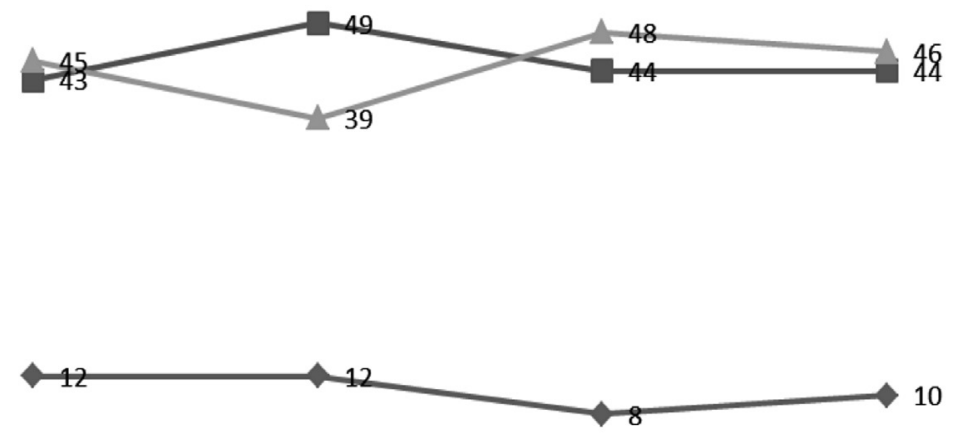

$2011 \mathrm{r}$.

2014 r.

$2016 r$.

2018 r.

$\multimap$ duże $\quad-$ umiarkowane $\quad \longleftarrow$ brak poczucia zagrożenia

Źródło: CBOS, komunikat z badań, Nr 61/2018, Poczucie bezpieczeństwa i zagrożenia przestepczością, maj 2018 r., \%.

\section{Podsumowanie}

Zabezpieczenie bezpieczeństwa obywatelom zgodnie z kulturą polityczną ustroju demokratycznego jest niekwestionowanym imperatywem dla struktur władzy na poziomie administracji rządowej, samorządowej, pozarządowej oraz przedsiębiorców i organizacji społecznych. 
Zatem w ramach odpowiedzi na pytanie, jak współcześnie kształtuje się postrzeganie bezpieczeństwa w naszym społeczeństwie, należy zwrócić uwagę na sprzężenie zwrotne zachodzące pomiędzy dwoma klasycznymi pojęciami, którymi są bezpieczeństwo i wolność.

Sprzężenie to układa się według następującego schematu: bezpieczeństwo przechodzi w wolność, a następnie wolność w bezpieczeństwo. Przy tak zarysowanym przedmiocie badań podmiotem będzie człowiek jako najwyższa wartość, której przysługuje prawo do wielowymiarowej ochrony przed zagrożeniami zagwarantowane w ustawodawstwie i systemach makrostrukturalnych, prawo do bezpieczeństwa na wszystkich poziomach. Ponadto można przyjąć, że współcześnie jednostka ludzka wyposażona jest w potencjał intelektualny i posiada stosowny poziom świadomości społecznej, w tym też świadomości dotyczącej bezpieczeństwa indywidualnego, ściśle powiązanego z innymi rodzajami bezpieczeństwa na mezo- i makropoziomach. W coraz bardziej złożonym i pełnym wyzwań technologicznych, gospodarczych i politycznych świecie bezpieczeństwo jako swoboda od zagrożeń wszelkiego rodzaju staje się fundamentalną wartością zinternalizowaną w procesie uspołecznienia jednostki ludzkiej i przejawia się w odpowiednim jej pojmowaniu oraz postrzeganiu różnych zagrożeń bieżących.

\section{Literatura}

CBOS (2014). Polacy o bezpieczeństwie narodowym i NATO - komunikat, Warszawa. CBOS (2018a). Bezpieczeństwo w internecie - komunikat, Warszawa.

CBOS (2018b). Poczucie bezpieczeństwa i zagrożenia przestępczościq - komunikat, Warszawa.

Fijalkowski, Ł. (2013). „Akt mowy” i „język bezpieczeństwa” a konstruowanie globalnych zagrożeń (dyskursywne podejście do bezpieczeństwa), „Kultura-Historia-Globalizacja" 14/2013. ISSN 1898-7265.

Gwoździewicz, S., Tomaszycki, K. (red.) (2017). Prawne i społeczne aspekty cyberbezpieczeństwa, Warszawa: Międzynarodowy Instytut Innowacji „Nauka-Edukacja-Rozwój”, Warszawa.

Kardash, O. (2017). Theoretical and Methodological Principles of the Country's Economic Security Assessment, "International Journal of New Economics and Social Sciences”, 2/6, s. 108-119. DOI: 10.5604/01.3001.0010.7628 ISSN: 2450-2146. 
Kitler, W. (2002). Obrona cywilna (niemilitarna) w Polsce, Warszawa: Egros. ISBN 8388185780 .

Korycki, S. (1994). System bezpieczeństwa Polski. Warszawa: AON.

Koziej, S. (2010). Wstęp do teorii i historii bezpieczeństwa, Internet: http://koziej.pl/wp-content/uploads/2015/05/Teoria_i_historia_bezpieczenstwa.doc (dostęp: 10 kwietnia 2018).

Lisiecki, M. (red.) (2008). Zarzadzanie bezpieczeństwem - wyzwania XXI wieku, Warszawa: Wydawnictwo WSZiP. ISBN 9788386228867.

Maslow, A.H. (1990). Motywacja i osobowość, Warszawa: PAX. ISBN 9788301148096.

Novikova, K. (2015). Urok niebezpieczeństwa: sieci społeczne a „niebezpieczne mody” wśród młodzieży i dzieci, „Journal of Modern Science”, 2/25, s. 53-64. ISSN 17342031.

Novikova, K. (2016), Zarządzanie sukcesem w rozwoju osobistym, „Journal of Modern Science", 4/31, s. 157-176. ISSN 1734-2031.

Pałka, D., Stecuła, K. (2018), Postęp technologiczny - dobrodziejstwo czy zagrożenie? W: R. Knosala (red.) Innowacje w zarzadzaniu i inżynierii produkcji. Tom 1. Opole: Oficyna Wydawnicza PTZP, s. 587-595. ISBN 9788393039975.

Pawlikowska, I. (2004). Bezpieczeństwo jako cel polityki zagranicznej państwa. W: R. Zięba (red.), Wstęp do teorii polityki zagranicznej państwa, Toruń: Wyd. Adam Marszałek, s. 61-63. ISBN 9788376113623.

Pokruszyński, W. (2012). Bezpieczeństwo: teoria i praktyka, Józefów: Wydawnictwo WSGE. ISBN 9788362753154.

Roman, Ł. (2015a). Identyfikacja bezpieczeństwa i obronności, „Journal of Modern Science", 3/26, s. 335-348. ISSN 1734-2031.

Roman, Ł. (2015b). Istota współczesnych wyzwań i zagrożeń bezpieczeństwa, „Journal of Modern Science", 4/27, s. 209-226. ISSN 1734-2031.

Roman Ł. (2016). Rzeczywistość kryzysu we współczesnych uwarunkowaniach polityczno-militarnych, „Journal of Modern Science”, 1/28, s. 369-388. ISSN 17342031.

Savina, N., Sribna, E. (2016). Problem Assessment of Energy Security in the Country, "International Journal of New Economics and Social Sciences", 2/4, s. 33-41. ISSN 2450-2146.

Słownik terminów z zakresu bezpieczeństwa narodowego (2002), Warszawa: AON. ISBN 8388062239. 
Stańczyk, R. (1996). Współczesne pojmowanie bezpieczeństwa, Warszawa: ISP PAN. ISBN 8386759135.

Stefanowicz, J. (1984). Bezpieczeństwo wspótczesnych państw, Warszawa: PAX. ISBN 8321106951.

Szafrańska, E., Szafrański, J. (2014). Edukacja na rzecz bezpieczeństwa, „Journal of Modern Science", 2/21, s. 211-233. ISSN 1734-2031.

Szczudlińska-Kanoś, A. (2013). Polityczne uwarunkowania zarządzania bezpieczeństwem wewnętrznym Polski, „Zeszyty naukowe WSOWL”, 3/169, s. 64-76. ISSN 1731-8157.

Szymczak, M. (red.) (1988). Słownik języka polskiego, Warszawa: PWN. ISBN 8301002824.

Wawrzusiszyn, A. (2016). Bezpieczeństwo wewnętrzne Polski wobec zagrożén międzynarodowych, „Journal of Modern Science”, 1/28, s. 217-232. ISSN 1734-2031.

Wyleżałek, J. (2012), Świat społeczny - świat jednostek. Co kształtuje człowiek(a)? Warszawa: Wydawnictwo SGGW. ISBN 9787875833577.

Zawisza, J., Ćmiel, S. (2012) Filozoficzne aspekty bezpieczeństwa strukturalnego $w$ kontekście bezpieczeństwa narodowego i międzynarodowego, „Journal of Modern Science" 3/14, s. 187-210. ISSN 1734-2031.

Zięba, R. (1999). Instytucjonalizacja bezpieczeństwa europejskiego, Warszawa: Scholar. ISBN 8387367761.

Zięba, R. (2008). Pozimnowojenny paradygmat bezpieczeństwa międzynarodowego. W: R. Zięba (red.), Bezpieczeństwo międzynarodowe po zimnej wojnie, Warszawa: Wydawnictwa Akademickie i Profesjonalne. ISBN 9788360501924. 
